\title{
Critical Posthumanism
}

Thorsten Botz-Bornstein*

\begin{abstract}
Uncritical Posthumanism" celebrates the continuation of the human by non-human means (for example, a new techno-bio body) as well as the creation of a reality by "unreal" means. Posthumanists attempt to make the body more self-contained and energy-efficient, developing the interaction of body-technology and consciousness-digitality, biotechnology or bioinformatics. The mutual interference of body, consciousness and reality creates a new space of "Virtual Reality." Critical Posthumanism attempts to disentangle the common characteristics of human reality and posthuman Virtual Reality and establishes communicative links between both by sticking to the conviction that simulation should never win over reality. Critical Posthumanism attempts to locate the human in the posthuman. This article analyzes the common points of Virtual Reality, biotechnology, and globalization by reflecting on the notion of the narrative. The existence of Virtual Reality, the gene-code, and globalization is due to the desire to elude any narrative and to express reality "directly." Gene technology tries to grasp not a certain - temporally definable - stage of the entire process of generation, but the gene itself, as the essential quantity of generation that has no real place in generation itself. Globalization "globalizes" the globe and represents it as something that is neither the "real world" nor its narration but rather a new sphere that we have to accept as such. Critical Posthumanism defines the subtle differences between a Virtual Reality in the sense of a technological narrative and an existential Virtual Irreality that interprets the virtual in a more "human" fashion.
\end{abstract}

Keywords: Critical posthumanism, virtual reality, narrative, human, posthuman.

\section{El Posthumanismo Crítico}

Resumen: el "Posthumanismo Acrítico" celebra la continuación de lo humano por medios no humanos (por ejemplo, un nuevo tecno-bio cuerpo), así como la creación de una realidad por medios "irreales". Los posthumanistas intentan lograr un cuerpo más autónomo y con eficiencia energética, desarrollando la interacción del cuerpo-tecnología y la conciencia- digitalidad, la biotecnología o la bioinformática. A través de la interferencia mutua del cuerpo, la conciencia y la realidad, se crea un nuevo espacio de "Realidad Virtual". El posthumanismo crítico intenta desenredar las características comunes de la realidad humana y la Realidad Virtual posthumana y establece vínculos comunicativos entre ambos, adhieriendose a la convicción de que la simulación nunca debe ganarse a la realidad. El posthumanismo crítico intenta ubicar al ser humano en el posthumano. Este artículo analiza los puntos comunes de la Realidad Virtual, la biotecnología y la globalización mediante una reflexión sobre la noción de la narración. La existencia de la Realidad Virtual, el código genético, y la globalización se debe al deseo de eludir cualquier narrativa y expresar la realidad "directamente". La tecnología de los genes no trata de entender alguna estapa - temporalmente definible - de todo el proceso de generación, sino el gen en sí mismo, como la cantidad esencial de

* Associate Professor of Philosophy, Gulf University of Science and Technology. Kwait. botz.t@gust.edu.kw

Recibido: 2012-05-16 Aprobado: 2012-06-09 
generación que no tiene lugar real en la generación en sí. La globalización “globaliza” el mundo y lo representa como algo que no es ni el "mundo real" ni su narración, sino más bien una esfera nueva que tenemos que aceptar como tal. El posthumanismo crítico define las diferencias sutiles entre una Realidad Virtual, en el sentido de una narrativa tecnológica, y una Irrealidad Virtual existencial que interpreta lo virtual en una forma más "humana".

Palabras clave: posthumanismo crítico, la realidad virtual, la narrativa, humano, posthumano.

\section{Le Post-humanisme Critique}

Résumé: Le "Post-humanisme acritique" célèbre la continuation de l'humain par des moyens non-humains (par exemple, un nouveau techno-bio-corps), ainsi que la création d'une réalité par des moyens "irréels". Les posthumanistes essaient d'obtenir un corps plus autonome avec une effcacité énergétique, développant l'intéraction du corps-technologie et la conscience-digitalité, la bio-technologie ou la bio-informatique. A travers l'interférence mutuelle du corps, la conscience et la réalité, se crée un nouvel espace de "Réalité Virtuelle". Le posthumanisme critique essaie de demêler les caractéristiques communes de la réalité humaine et de la Réalité Virtuelle post-humaine, et établit des liens communicatifs entre eux; s'adhérant ainsi à la conviction que la simulation ne doit jamais vaincre la réalité. Le posthumanisme critique essaie de situer l'être humain dans le posthumain. Cet article analyse les points communs de la Réalité virtuelle, la bio-technologie et la globalisation à travers une reflexion sur la notion de narration. L'existence de la Réalité Virtuelle, le code génétique, et la globalisation est due au désir d'éluder toute narrative et d'exprimer la réalité "directement". La technologies des gènes n'essaie pas de comprendre une étape - temporairement définissable - de tout le processus de génération, mais le gène en soi, comme la quantité essentielle de génération qui n’a pas de place réelle dans la génération en soi. La globalisation "globalise" le monde et le représente comme une chose qui n'est ni le "monde réel" ni sa narration, mais plutôt une sphère nouvelle que nous devons accepter en tant que telle. Le posthumanisme critique définit les différences subtiles entre une Réalité Virtuelle,dans le sens d'une narrative technologique et une Irréalité Virtuelle existentielle qui interprète le virtuel d'une façon plus "humaine".

Mots-clés: Posthumanisme critique, la réalité virtuelle, la narrative, humain, posthumain. 


\section{Critical Posthumanism}

Even if one is tempted to ridicule an elastic concept such as "postmodernism" because of its largely unspecified character one has to admit that during the last thirty years or so, together with the rejection of totalilizing concepts such as "progress," "race," "rigor," etc., also the idea of the "human" has suffered and will most probably continue to do so. ${ }^{1}$ In the present article I attempt neither to embrace the posthuman as an exciting adventure nor to reinstall "humanism" but rather to steer a middle course able to locate the human in the posthuman. This is what I see as the task of Critical Posthumanism.

Critical Posthumanism exists already in various forms, reaching from straightforward anti-cloning campaigns to sophisticated studies informed by disciplines such as structuralism, feminism, and postcolonial studies. My Critical Posthumanist agenda consists in characterizing the posthuman world as the latest grand narrative that humanity has produced, the narrative of Virtual Reality. Most generally, "narrative" is defined as "the representation of an event or a series of events" (Abbot 2002: 12). Lyotard's statement that "the grand narrative [progress, Marxism, etc.] has lost its credibility" (Lyotard 1984: 37) has generally been accepted but I believe that it is still possible to describe the whole process of civilization as a process that transforms reality into a mediated, narrated reality. And Virtual Reality (including its posthuman extensions) represents the last stage of a continuous development.

1 On the definition of Critical Posthumanism see Callus and Herbrechter 2008.

\section{Uncritical Posthumanism}

"Uncritical Posthumanism" (I avoid calling it "Popular Posthumanism" or "Transhumanism" though some people do, see Simon 2003) celebrates the continuation of the human by non-human means (for example, a new techno-bio body) as well as the creation of a reality by "unreal" means. Both celebrations are interlinked but let us start with the body. Originally, uncritical Posthumanism developed around an outspoken appeal for the cyborg in the 1980s and 1990s and fostered an intellectual attitude that sees the body as a commodity malleable in the hands of modern technology predicting a prosthetic "biocultural" future. This attitude is often sparked off by a "weariness with the human condition itself" (Baillie and Casey 2005: 31). In 1991 the artist Stelarc announced that it is "time to question whether a bipedal, breathing body with binocular vision and a 1,400cc brain is an adequate biological form" (Stelarc 1991: 591). Equally in the early nineties, the "World Transhumanist Association" declared that "humanity will be radically changed by technology in the future. We foresee the feasibility of redesigning the human condition" (quoted from Winner 2005: 392). Closely linked to this adventure are ambitions to make life eternal, as they were pronounced by Human Genome Science CEO William Haseltine who said that "as we understand the body's repair process at the genetic level $[. .$.$] we will be able to advance$ the goal of maintaining our bodies in normal function perhaps perpetually" (quoted from Fukuyama 2002: 18).

All these statements concern the body which posthumanists attempt to make "more self-contained [and] energy-efficient" (Stelarc 
1991: 592). It goes without saying that the brain represents a similar challenge. Strictly speaking, it is not the brain as a self-contained machine that fascinates Posthumanism; such an entity is rather an object of interest for more technical branches of cognitive science. The item that has received a good deal of interest in posthuman theory is the consciousness as a mixture of intellectual, bodily, and spatial awareness. While bioengineering and nanotechnology (which develops molecular-scale self-replicating machines) establish a posthuman body, digitality establishes a consciousness able to function posthumanly. Katherine Hayles thinks that the coupling of human cognition to digital machinery makes the construction of posthuman beings possible (Hayles 1999: 3). Things become compelling and much more dynamic at the moment the cognitive-digital domain and the prosthetic-bodily domain overlap. "Merging with computerized entities requires an extension of our humanity," writes Michael Heim (Heim 1998: 62). While a first phase of Posthumanism came of age simply through the coupling of the natural and the technological, a second phase announced itself through the interaction of body-technology and consciousness-digitality, biotechnology or bioinformatics, as mergers of biology and information technology, let computers interpret and build models provided by biological sciences, especially genomics. "Biological and digital domains are no longer rendered ontologically distinct," writes Eugene Thacker (2004: 7), which means that the posthuman reality is no longer a reality "out there" but a realm established in relationship with both consciousness and the body. "The biological 'informs' the digital just as the digital 'corporealizes' the biological," continues Thacker (7). It becomes clear that the body is no longer, as Hans Moravec still postulated, a container of consciousness that can one day be cast away because "consciousness" can be unloaded into some sort of brain vat (cf. Moravec 1992). ${ }^{2}$ On the contrary, the body itself is both biomolecular and "'compiled' through modes of visual-

2 See also "Simulation, Consciousness, Existence" available from Moravec's website. ization, modeling, data extraction, and in siclo simulation" (Thacker 2004: 13). To this must be added the fact that biotechnology is more and more web-based and takes place in a web-lab.

The Copernican revolution led humanity to recognize that it did not stand at the center of the universe; the genomic revolution showed us that we are "the most undistinguished spot at the periphery of evolution" (Sagoff 2005: 68); finally, the digital revolution shows us that reality itself is not a stable platform on which we can stand but that it is manipulable, prone to all sorts of combinations and hybridizations dependent on consciousness and the body.

\section{A World of Paradoxes}

From the preceding explanations follows that Critical Posthumanism must be concerned with paradoxes. The first paradox is that, on the one hand, Virtual Reality is de-centered, playful, godless, and disenchanted because all truths it contains have been made and not found; ${ }^{3}$ and that on the other hand, for reasons of this reality's synthetic power of identification and expansion or simply because of its all-inclusiveness, it can also be seen as transcendental. When Robert Pepperell writes that "recent theories of quantum physics have suggested that the traditional division between mind and reality is in doubt" (Pepperell 2003: 6), what he means is not so much that reality will be submitted to a Humeian sort of Matrix-like subjectivism in which "embodiment has become irrelevant" (Wolmark 2002: 83). His point is rather that in posthuman reality the relation between consciousness (traditionally defined as feelings, emotions, memories, and other mental states) and the world is no longer limited to subjectivism or objectivism but that from now on consciousness is not in the brain alone but "distributed throughout the whole body" (Pepperell 2003: 4). This means that the posthuman condition is not limited to the replacement of body parts with technological items but con-

3 The distinction between made and found truth comes from Rorty 1989: 53. 
cerns a change of consciousness. It concerns all mental states including that of eroticism, which becomes a sort of "techno-eroticism" (cf. Springer 1996) directed, for example, towards the Japanese Mecha Shôjo (Mecha Musume in the West) who is a combination of a beautiful girl and a (weapon like) machine.

A statement by the British writer J.G. Ballard illustrates in a particularly graphic way the consequences that this will have for the life of humans: "I believe that organic sex, body against body, skin area against skin area, is becoming no longer possible [...]. The whole overlay of new technologies are beginning [...] to reach into our lives and change the interior design of our sexual fantasies" (Ballard 1984: 157; quoted from Shigematsu 1999: 127). A. Newitz has even an original explanation for the "naturalness" of the Mecha Shôjo: "female bodies are [...] best suited to mecha [...] precisely because it is related to reproduction and giving birth" (Newitz 1995: 9).

All this shows that Virtual Reality as well as the posthuman world of bioengineered beings is not a utopian, "second world" that can be enthusiastically embraced or refused. On the contrary, in this new world "reality" as much as the body with all its traditional quests continue to exist. It is rather through the mutual interference of body, consciousness and reality that a new space of Virtual Reality is created. And since consciousness is located in the body as much as in the space within which this body acts, space requires an entirely new dimension as we can guess by simply reading the title of Gregory Stock's book Metaman: The Merging of Humans and Machines into a Global Superorganism. In this book the author claims that the "progressively deepening union between humans and machines is symbiotic" (Stock 1993: $60)$ and will eventually develop into a "planetary creature" (53).

The role of Virtual Reality in a posthuman world can only be understood within the network of these links that exist between consciousness, reality, and the body. Virtual Reality is not just a new kind of space but has replaced a certain spontaneity of direct perception - that could traditionally be defined as a straightforward relationship between the subject and the object - with a sort of commodified "second world" that it constantly reproduces.

Francis Fukuyama discusses in his Our Posthuman Future Aldous Huxley's Brave New World and common reactions to his world as a realm in which people "may be healthy and happy, but [...] have ceased to be human" because Huxley's system is "against human nature" (Fukuyama 2002: 6). Fukuyama ridicules these reactions because neither "being human" nor its importance can be defined in an absolute manner (Fukuyama largely follows Leon Kass's interpretation of Huxley, [Kass 2001]). Any arguments reproaching the Brave New World and its intrinsic inhumanism (or Posthumanism) establish, so Fukuyama finds, "the human" in a circular fashion as an ethical ground and at the same time as a value dependent on this ground.

Fukuyama's discussion of Huxley does not lead towards a defense of Brave New World schemes but rather towards the recommendation of tough government checks in order to prevent the breeding of "people with saddles on their backs" (9). This is Fukuyama's version of "Critical Posthumanism." However, his almost hysterical focus on inhuman bioengineering but simultaneous lax dismissal of anything intrinsically inhuman in the Brave New World is alarming. In my opinion, what the people in The Brave New World loose is not an objectified version of "human" characteristics but simply reality. At the moment they "no longer struggle, aspire, love, [and] feel pain" (Fukuyama) they live in a dreamworld in which nothing ever signals that things do really exist. This concept of "reality as resistance" helps to understand what is at stake in discussion on Virtual Reality and bioengineering. Huxley is not at all recommending to "continue to feel pain, be depressed or lonely," as Fukuyama tries to make us believe, but points to the importance 
of clinging to reality as "the true, yet ephemeral fruit of human life" which is "the surprise [and] the beauty [...]" (Baillie 2005: 231) and which some kind of Virtual Reality attempts to undermine but which remains the only world that it is worth living in.

Critical Posthumanism, far from diabolizing Virtual Reality and bioengineering, settles somewhere between extreme idealism and naïve realism. It attempts to disentangle the common characteristics of human reality and posthuman Virtual Reality and to establish communicative links between both by firmly sticking to the Baudrillardian conviction that simulation should never win over reality. This is how it will be able to locate the human in the posthuman.

As mentioned, the de-centered, playful narrative of Virtual Reality that is at the same time universal or even transcendental asks for an approach able to take into consideration paradoxes. As a matter of fact, in terms of methodology, Critical Posthumanism enters a ground that is not well trodden because such curious conceptual combinations of subjectivity and pretensions towards something absolute remain rare in the history of Western thought. Kant's sensus communis comes to mind because, just like Kant's construct, the narrative of Virtual Reality is simultaneously intimate and universal. Kant introduced the term sensus communis as a theoretical tool able to grasp the intrinsic character of aesthetic expressions. To Kant it was obvious that aesthetic judgments are subjective, that they are made and not found by reason in the form of rational rules. However, at the same time he saw that these subjective judgments need to be also universal: what one person judges to be beautiful must also be found beautiful at least by many others, otherwise the idea of the beautiful does not make sense. Therefore Kant introduces, in Section 20 of the Critique of Judgment, the sensus communis (Gemeinsinn) as the human ability to judge according to the same "feeling" (sensus, Gefühl), which is subjective though at the same time universal and transcendental. Aesthetic judgments are declared to be tran- scendentally valid through a paradoxical sensus communis. ${ }^{4}$ As shown above, Virtual Reality is based on a similarly paradoxical constellation and Critical Posthumanism must take this into consideration. The playful and subjective narrative of Virtual Reality is at the same time an All-Unity.

Virtual Reality represents the idea of a nonphysical space enabling man to grasp the world as a whole. Originally, in the history of philosophy, the religious idea of All-Unity contained a "tragic" and existential moment. However, this tragic moment was stifled in the Renaissance through the invention of "perspective." In Renaissance, according to the Russian philosopher Berdiaev, "the inner drama and dynamic stirring related to religious experience were replaced by a single, static, idolizing gaze dependent only on one single perspective" (Berdiaev 1930: 51). Virtual Reality now offers a new consciousness of the whole.

Critical Posthumanism approaches Virtual Reality through still two other paradoxes. A further paradox is represented by the fact that, in principle, there is no reason to call the posthuman reality "posthuman" because, after all, it is a project led by humans.

Still another paradox has to do with the peculiar status of immediacy in Virtual Reality. On the one hand, our postmodern civilization is dominated by the desire to elude narratives and to experience reality "immediately," that is in an "unmediated" way and in "life" time. On

4 The sensus communis has nothing to do with "common sense." As an aesthetic notion it maintains a very indirect relationship with the social phenomenon of the community. Cf. $\S 20$ of Kant's Critique of Judgment (entitled: "The Condition for the Alleged Necessity by a Judgment of Taste is the Idea of a Common Sense"): "If judgments of taste had (as cognitive judgments [Erkenntnisurteile] do) a determinate objective principle, then anyone making them in accordance with that principle would claim that his judgment is unconditionally necessary. If they had no priciple at all, like judgments of the mere taste of sense [des bloßen Sinnengeschmacks], then the thought that they have a necessity would not occur to us at all. So they must have a subjective principle, which determines only by feeling rather than by concepts, though nonetheless with universal validity [allgemeingültig], what is liked or disliked. Such a principle, however, could only be regarded as common sense [Gemeinsinn]; for the latter judges not by feeling [Gefühl] but always by concepts [Begriffe], even though these concepts are usually only principles conceived obscurely." (English translation by Werner Pluhar 1987. Original: 237-38). See also Kimmerle 2000. 
the other hand, the methods that are pursued in order to enable this experience are technological and create a second hand reality that, in return, closely resembles a narrative.

\section{Psychoanalysis, Gene-Technology, Globalization, Virtual Reality}

Four cultural paradigms are determined by a shift from an "original event" to a virtual "narrative": psychoanalysis, gene-technology, Virtual Reality, and globalization. Psychoanalysis transformed the dream into a narrative, and, consequently, was able to spell out the dream's symbols. Similarly, gene-technology narrates dynamic, self-evolving evolution as a "gene code." This means that what has first been "nothing" but an undeterminable process of "generation" is now spelled out in the form of a code containing "genes" as elements constituting "generation." Finally reality itself (with all its dreamlike and perhaps virtual components) also has come to be narrated in the form of a second reality that is called "virtual." One might say that the only phenomenon that has not yet been fully "narratized" is "the world," though the discourse on "globalization" (in French "mondialisation," which means "worldization") does its best to let the globe appear as once more globalized because reproduced through narrative.

In spite of its consistency, a decisive aspect needs to be considered within this version of a history of civilization, an aspect which flows out of the very nature of the new element called "the virtual." The model of the "the world as a narrative" makes most sense in regards to Freud when he tried to transform dreams into narratives in order evaluate them scientifically. It still makes sense in regards to television or the media in general. The particular point about the above-mentioned, more recent, phenomena succeeding psychoanalysis is, however, that these phenomena attempt to reach back to an "originality" that is not simply an "event." In other words, what is at stake in Virtual Reality, gene-technology, and globalization is much more than the desire to "narrate the world." The striking point about Virtual Reality, the gene-code, and globalization is that even if these phenomena end up as nothing more than as a narrative of something that exists "out there," their existence itself is due to the desire to elude any narrative and to express reality "directly." Gene technology tries to grasp not a certain - temporally definable - stage of the entire process of generation, but the gene itself, as the essential quantity of generation that has no real place in generation itself. This means that in popular bio-genetics genes have a virtual character. Though Baillie and Casey believe that "genetic mapping and sequencing have [not] yielded the meaning of life" (Baillie and Casey 2005: 10), it is clear that the map of genes is a certain kind of narrative. However, genes never tell a story about reality but they generate a Virtual Reality of their own. It seems that large part of the popular fascination with genes is derived from this virtual character of genes. "Reality" tells us that the logic underlying historical processes as well as biological formation (a logic by which philosophers have often been fascinated) cannot be grasped because, "in reality," this logic is nothing. Through genetics however, a part of this logic can suddenly be crystallized within a kind of "narrative" presented in the form of the "genetic map." Along these lines, genes are telling a posthuman narrative which, as Halberstam and Livingston have said, has "replaced previous masternarratives about humanity" (Halberstam and Livingston 1995: 4).

The Matrix is such a posthuman narrative because it effectuates a shift from human "real" reality to a posthuman Virtual Reality. However, this shift is relatively simplistic and represents a typical vision of uncritical posthumanism. The "cognitive manipulations" thesis of The Matrix produces a one-dimensional model of reality as well as of "humanity." A narrative exemplifying Critical Posthumanism would be Andrei Tarkovsky's Solaris and Stalker because in these films it remains entirely undefined what it ac- 
tually means to be human. As a consequence, in Solaris and in Stalker the establishment of a posthuman reality is also more ambiguous.

Narrated reality functions as a substitute reality. Such a narrated reality is represented by Virtual Reality, by eternal life obtained through cloning, as well as by a globalized world (as it designs itself as a repository of the end of history, or as a state of world civilization hardened through opposing core civilizations). Globalization "globalizes" the globe and represents it as something that is neither the "real world" nor its narration but rather a new sphere that we have to accept as such.

\section{Critical Posthumanism and Interculturality}

It must be pointed out that Posthumanism has a different face in Far Eastern traditions. It has often been remarked that the distinction between humans that have a soul and animals that have no soul does not exist in non-Christian cultures. As a consequence, Posthumanism is received in these cultures with less concern. This attitude can partly be traced to Buddhism and Shintoism, which holds that all objects possess a spirit (see Bartneck et al. 2007). The Japanese, for example, distinguish less strictly the artificial from the natural, and Frédéric Kaplan finds that for the Japanese "building machines is a positive activity in search of the natural laws that govern [the world]" (Kaplan 2004: 9; and Gilson 1998). In Japan, which is, according to Ian Buruma, "at once one of the most natural and the most artificial of places" (Buruma 1984: 110), the distance between humans and machines is less large and robots are judged from a more aesthetic point of view. Japanese robots can even contain a considerable amount of cuteness. This does not mean that Japanese would be uncritical towards artificial life; especially hybridizations of humans and machines (cyborgs) are not met with much enthusiasm (Kaplan 2004: 3). Polls have shown that Japanese are most worried about the emotional impact of robots, a concern less frequently expressed by Americans (Bartneck et al. 2007). Curiously, real human beings can adopt in Japan a robot like existence as is often the case with doll-like television talantos, teen stars artificially created through choreographed movements and mechanical smiles who seem to be appreciated by the public because of their flagrant lack of humanity (cf. Buruma 1984: 68).

For this reason also the aforementioned posthuman indistinction between the subject and "reality" obtains a new status in the context of East-Asian cultures. David Peat writes about the East-Asian concept of "reality":

This holistic notion of the atomic world was the key to Bohr's Copenhagen interpretation. It was something totally new in physics, although similar ideas had long been taught in the East. For more than 2000 years Eastern philosophers has talked about the unity between the observer and that which is observed. They had pointed to the illusion of breaking apart a thought from the mind that thinks the thought. ${ }^{5}$

Most evidently, out of these constellations will also flow peculiar concepts of "Virtual Reality" and they are most visible in the domain of aesthetics. Specialists of Far Eastern art explain that in the East, art is always necessarily virtual. For Ryôsuke Ohashi, for example, Japanese culture attempts to attain a vision of the real world as something virtual by means of an aesthetics of the virtual. According to him, in Japanese culture the paradox which makes the imagined "nonreal" more existential than the "virtual real" disappears. Art is a Virtual Reality as it exists not only for itself but also permits us to recognize the virtual character of all reality. ${ }^{6}$

In the "West" the virtual has a different status. When, quite unexpectedly, the term "Virtual Reality" was introduced to the public in the late 1980s and consequently examined by Western thought, it appeared, curiously, not as

David Peat, Einstein's Moon, quoted from Pepperell 2003: 6.

6 Ohashi 1999: 91ff. For further developments of this topic see the chapter on Noh-plays and icons in Botz-Bornstein 2008. 
a component of art but in the form of a quality sticking to a kind of non-existent space created by computers and through electronic communication. For reasons that would never really be examined, it seemed to be predestined to function as an integral element of a posthuman type of new reality. Philosophy tried to disentangle some of these concepts, which was, of course, no easy task. There was almost nowhere to look for philosophical approaches that would systematically explain the nature of the virtual. The only thing that was clear from the beginning was that Virtual Reality was not simply a matter of illusion (similar to postmodern simulation) created by sophisticated technology. Though formally, Virtual Reality appeared to be very much like television, it also included a psychologically and ontologically disquieting quantity. Terms like "transcendentality" or "Absolute Spirit" quickly occurred and could not be eradicated since. To many, virtual space spontaneously appeared as something "spiritual" though a human or aesthetic quality of the virtual would never gain over the posthuman, technological one.

\section{Conclusion}

My claim is that the phenomenon commonly known as "Virtual Reality" should be opposed to a more intimate type of Virtual Reality that does not aspire to create, as does the latter, a second reality, but that creates an irreality. ${ }^{7}$ Virtual Reality lacks the existential component that Virtual Irreality considers as its main purpose of existence. The shift from Posthumanism to "Critical Posthumanism" is effectuated through this distinction. What distinguishes the Virtual Irreality from common, technological Virtual Reality is that the latter follows the principal lines of Western aesthetics and attempts to establish an alternative kind of "virtual realism" by means of logic and reason. Zola's approach of capturing "life itself" is based on the "reasonable" approach of attempting to reproduce reality. It is opposed to

7 The term Virtual Irreality is in agreement with Michael Heim's definition of "Irrealism" (Heim 1998: 216).
"Romantic" ways of grasping the world based on personal feelings and other subjective components. However, even when reality is perfectly "represented" to the point that it appears as absolutely real, the fact to re-present something cannot escape subjectivism. What Zola can be reproached with represents also the weakest point of computerized Virtual Reality. Critical Posthumanism has to define the subtle differences between a Virtual Reality in the sense of a technological narrative and an existential Virtual Irreality that interprets the virtual in a more "human" fashion.

\section{Bibliography}

Abbot, Porter. 2002. The Cambridge Introduction to Narrative. Cambridge: Cambridge University Press.

Baillie, Harold, and Timothy Casey, eds. 2005. Is Human Nature Obsolete? Genetics, Bioengineering, and the Future of the Human Condition. Cambridge: MIT Press.

Baillie, Harold. 2005. 'Aristotle and Genetic Engineering: The Uncertainty of Excellence'. In Is Human Nature Obsolete? Genetics, Bioengineering, and the Future of the Human Condition, edited by Harold Baillie and Timothy Casey, 209-232. Cambridge: MIT Press.

Ballard, James G. 1984. “Interview by Lynn Barber." Re/Search 8-9: 157.

Bartneck, Christoph, and Tomohiro Suzuki et al. 2007. "People's Culture and Prior Experiences with Aibo Towards Robots." AI Society: The Journal of Human-Centered Systems 21: 1-2, 217-230.

Berdiaev, Nicolai A. 1930. "Iz etiudov o ya beme: etiud 1. Uchenie ob ungrunde i svobodie" ['Studies Concerning Jacob Böhme Etude I: The Teaching about the Ungrund and Freedom']. Put' 20: 47-79.

Botz-Bornstein, Thorsten. 2008. Space in Russia and Japan: A Comparative Philosophical 
Study. Lanham: Lexington-Rowman \& Littlefield.

Buruma, Ian. 1984. Behind the Mask. New York: Pantheon Books.

Callus, Ivan, and Stefan Herbrechter. 2008. Critical Posthumanism: An Introduction. Amsterdam \& New York: Rodopi.

Fukuyama, Francis. 2002. Our Posthuman Future: Consequences of the Biotechnology Revolution. New York: Farrar, Straus \& Giroux.

Gilson, Marc. 1998. “A Brief History of Japanese Robophilie." Leonardo 31, 15: 367-369.

Halberstam, Edith, and Ira Livingston. 1995. Posthuman Bodies. Bloomington: Indiana University Press.

Hayles, Katherine. 1999. How We Became Posthuman: Virtual Bodies in Cybernetics, Literature, and Informatics. Chicago: Chicago University Press.

Heim, Michael. 1998. Virtual Realism. New York: Oxford University Press

Kant, Immanuel. 1908. Kritik der Urteilskraft. Berlin: Reimer. [Engl.: Critique of Judgment. Translated by Werner S. Pluhar. Indianapolis: Hackett, 1987].

Kaplan, Frédéric. 2004. "Who is Afraid of the Humanoid? Investigating Cultural Differences in the Acceptance of Robots." International Journal of Humanoid Robotics 1: 3, 465-480.

Kass, Leon. 2001. "Preventing a Brave New World: Why We Should Ban Cloning Now." The New Republic, 21, 30-39.

Kimmerle, Heinz, and Henk Oosterling, eds. 2000. Sensus communis in Multi- and Intercultural Perspective: On the Possibility of Common Judgments in Arts and Politics. Würzburg: Königshausen \& Neumann.
Lyotard, Jean-François. 1984. The Postmodern Condition: A Report on Knowledge. Minneapolis: Minnesota University Press.

Moravec, Hans. 1992. Une Vie Après la Vie. Paris: Odile Jacob.

Newitz. 1995. "Magical Girls and Atomic Bomb Sperm: Japanese Animation in America." Film Quarterly, December, 1-15.

Ohashi, Ryôsuke. 1999. "Phänomenologie der Noh-Maske." Japan im interkulturellen Dia$\log$. München: Iudicium.

Peat, David. 1990. Einstein's Moon: Bell's Theorem and the Curious Quest for Quantum Reality. Chicago: Contemporary Book.

Pepperell, Robert. 2003. The Post-Human Condition: Consciousness Beyond the Brain. Bristol and Portland OR: Intellect.

Rorty, Richard. 1989. Contingency, Irony and Solidarity. New York: Cambridge University Press.

Sagoff, Mark. 2005. "Nature and Human Nature." In Is Human Nature Obsolete? Genetics, Bioengineering, and the Future of the Human Condition, edited by Harold Baillie and Timothy Casey, 67-98. Cambridge: MIT Press.

Shigematsu, Setsu. 1999. "Dimensions of Desire: Sex, Fantasy, and Fetish in Japanese Comics." Lent 21, 3: 127-163.

Simon, Bart. 2003. "Introduction: Toward a Critique of Posthuman Futures." Cultural Critique 53 (special issue 'Critical Posthumanism'); 1-9.

Springer, Claudia. 1996. Electronic Eros: Bodies and Desires in the Post-industrial Age. Austin: University of Texas Press.

Stelarc. 1991. "Prosthetics, Robotics and Remote Existence: Postrevolutionary Strategies." Leonardo 24, 5: 591-595. 
Thorsten Botz-Bornstein

Stock, Gregory. 1993. Metaman: The Merging of Humans and Machines into a Global Superorganism. New York: Simon \& Schuster.

Thacker, Eugene. 2004: Biomedia. Minneapolis: Minnesota University Press.

Winner, Langdon. 2005. "Resistance is Futile: The Posthuman Condition and its Advocates" In Is Human Nature Obsolete? Genetics, Bioengineering, and the Future of the Human Con- dition, edited by Harold Baillie and Timothy Casey, 385-412. Cambridge: MIT Press.

Wolmark, Jenny. 2002. "Staying with the Body: Narratives of the Posthuman in Contemporary Science Fiction." In Edging into the Future: Science Fiction and Contemporary Cultural Transformation, edited by Veronica Hollinger and Joan Gordon, 75-89. Philadelphia: University of Pennsylvania Press. 